\title{
Legislative Enforcement of Contractual Fairness in Malaysian Consumer Contracts
}

\author{
Farhah Abdullah ${ }^{1}$, Ong Tze Chin ${ }^{2}$, \\ Mohd Safri Mohammed Na'aim ${ }^{3}$, Nor Honey Dayatie ${ }^{4}$ \\ ${ }^{1}$ Faculty of Law, \\ Universiti Teknologi MARA Shah Alam, Selangor, Malaysia \\ ${ }^{2}$ Faculty of Business, Communications, Accountancy and Law, \\ INTI International University Nilai, Malaysia \\ ${ }^{3}$ Faculty of Law, \\ Universiti Teknologi MARA Shah Alam, Selangor, Malaysia \\ ${ }^{4}$ Faculty of Islamic Studies, \\ University Kebangsaan Malaysia, Malaysia
}

farhah2016@gmail.com, tzechin81@yahoo.com, safri7246@uitm.edu.my, nhani1310@gmail.com

\begin{abstract}
Consumers faced with contract do not know what 'small print' contains or understand its effect. Exclusion clauses may deprive a consumer of specific rights in which he deserves protection. The Consumer Protection Act 1999 in Malaysia, allows the consumers to identify between procedural unfairness and substantive unfairness. However, the Consumer Protection Act 1999 does not adequately protect the consumer. By applying the content analysis research method, this paper reviews the legislative and judicial intervention on unfair terms in consumer contracts. This article advocates that Malaysia should establish a specific framework on consumer law protection against unfair terms in consumer contracts.
\end{abstract}

Keywords: Exclusion clauses; unfair terms; consumer contracts; judicial-legislative intervention

eISSN 2514-7528 @ 2019. The Authors. Published for AMER ABRA cE-Bs by e-International Publishing House, Ltd., UK. This is an open-access article under the CC BY-NC-ND license (http://creativecommons.org/licenses/bync-nd/4.0/). Peer-review under responsibility of AMER (Association of Malaysian Environment-Behaviour Researchers), ABRA (Association of Behavioural Researchers on Asians) and cE-Bs (Centre for EnvironmentBehaviour Studies), Faculty of Architecture, Planning \& Surveying, Universiti Teknologi MARA, Malaysia. DOI: https://doi.org/10.21834/jabs.v4i13.334 


\subsection{Introduction}

The approach of paternalistic seems to be essential in protecting consumers, especially with the vast awareness of consumerism at the global scale in this new millennium, along with interventions of legislative and judicial aspects. This revolution in consumerism seems to dismiss the concept of laissez-faire that highlights freedom of contract in the era when consumer rights had been absent. The very notion of consumerism is born mainly because of increasing conceptions that were against the idea of laissez-faire. Freedom of contract is applied by those unethical to manipulate consumers by embedding an exclusion clause. The disparity in knowledge between consumers and traders has left consumers with insufficient information to ensure a fair and balanced contract. Thus, the government devises consumer protection laws in order to ascertain laws linked to consumer protection blanket both public and private laws. (Naemah, 2012) In reality, most exclusion clauses have been embedded by traders in consumer contracts for exemption of liability at contract breaches. Hence, the paper aims to elaborate on the real implications of the consumers within the modern economy are faced with unequal bargaining power, thus demanding protection for those vulnerable and weak groups (Sinnadurai, 1978). Thus, this effort is deemed essential in safeguarding a fair dealing between consumers and traders, especially in addressing exemption clauses that put consumers on the losing end. This approach is an essential feature of legislation of consumer protection is essential equality in bargaining power between consumers and traders by (i) correcting the imbalance in economic power between individual buyer and traders for services and goods; (ii) reducing incidences of losses and deficits related to purchase by protecting consumers from unfair trade practices. (Rachagan, 2007).

The consumers within the modern economy are faced with unequal bargaining power, thus demanding protection for those vulnerable and weak groups. The disparity in knowledge between consumers and traders has left consumers with insufficient information to ensure a fair and balanced contract. Thus, consumer protection laws have been devised in order to ascertain a fair dealing between consumers and traders, especially in addressing exemption clauses that put consumers on the losing end - laws linked to consumer protection blanket both public and private laws (Naemah, 2012). To Rachagan (2007), legislation of consumer protection ensures equality in bargaining power between consumers and traders by: (i) correcting the imbalance in economic power between individual buyer and traders for services and goods; (ii) reducing incidences of losses and deficits related to purchase by protecting consumers from unfair trade practices and unsafe products; and (iii) ensuring equitable distribution in the society for deficits through apt laws of product liability.

The two essential aspects for a bullish economy are an independent judiciary and contract law (Buckley, 2005). According to Sinnadurai (2011), the Malaysian courts have made use of the principles of common law to address cases related to exclusion clauses, for instance, Parker v South Eastern Railway Co., Chapelton v Barry UDC, Thornton v Shoe Lane Parking, as well as Olley v Marlborough Court Ltd. Sakina (2009) asserted that legal cases involving exclusion clauses in Malaysia seem to have been recorded since the late 1950s with the Sze Hai Tong Bank Ltd v Rambler Cycle Co Ltd. Most exclusion clauses dealt in Malaysian courts are related to authorities from the ports due to contracts of bailment, while cases of exclusion clauses that involve consumers appear uncertain mainly because 
of the various stances held by judges (Sakina, 2009).

\subsection{Literature Review}

Yates (1986) had defined 'exemption or exclusion clause' as "any clause in a contract or term in a notice that purports to restrict, exclude or modify a liability, duty or remedy that would otherwise arise from a legally recognized relationship between the parties." Such clause had been common during the $19^{\text {th }}$ century primarily because of the strong concept of freedom of contract that was legal in trades and purchases. Meanwhile, Atiyah (1995) claimed: "an exclusion clause may be in numerous forms, but they share one similar aspect, which is an exemption from liability of a party that should be held responsible if the clause is absent."

Exclusion clauses come in varied types and classifying them is impossible (Poole, 2008). Moreover, new exclusion clauses are always generated to override the steps taken by the courts to put a halt to this tricky act. Generally, these exclusion clauses can be categorized into three types:

i) Most common: These exclusion clauses are embedded in contracts to state exclusion from liability. For instance, liability exclusion from losses that are substantial, in which the clause may limit the payable liability to only a certain amount, such as the payable sum stipulated in a contract.

ii) Other common forms: Clauses that place a limit to an available remedy by implying a short duration for breached claims or impossible conditions to obtain a remedy, for example, transportation costs for faulty products.

iii) More difficult to control: This kind of clause alters the obligation towards performance, instead of liability exemption, in order to ensure nil breach.

Syed Ahmad Alsagoff (2007) pointed out that, "these (exemption) clauses may appear in printed tickets, notices or receipts which are brought to the customers' attention at the time of the agreement which, in most cases, the consumers do not have time or energy to read the printed words. Although the consumers read them, they would probably not understand them. The consumers would only realize their limited rights upon a dispute all due to the exclusion clauses.

\subsection{Methodology}

This legal research had employed legal approaches to gather, discuss, explore, elaborate, examine, validate, interpret, and present both the data and the outcomes. The data gathered were analyzed by adopting the four legal research approaches historical, jurisprudence, comparative, and analytical, as well as several critical approaches with a view of reforming the law on the given subject matter. The four major standpoints, as elaborated by Walker (1969), are given in the following:

...these are analytical, breaking down the problem-situation and ascertaining what elements compose it and what rules are applicable to each part of the subject and its problems; the historical, ascertaining how and why these rules have come to be accepted and to take their modern form; the philosophical considering whether those rules are consistent with the needs of society, and with 
accepted ideas of right and justice; and the comparative, seeing how other societies at a similar stage of civilization face-up to the same or corresponding problems. For proper appreciation, that is, one must find out what the rules are here and now, what they once were and how, and why they come to be what they are, whether satisfactory judged by an ideal standard, and how they appear compared with the rules that are accepted elsewhere.

Also, Terry Hutchinson stated "Research which intensively evaluates the adequacy of existing rules and which recommends changes to any rules found wanting. Doctrinal research is library-based, focusing on a reading and analysis of the primary and secondary materials. The primary materials are the actual sources of the law-the legislation and case law. The secondary materials include the commentary on the law found in textbooks and legal journals. Often, reference sources such as legal encyclopedias, case digests, and case citators are needed to index and access the primary sources." Doctrinal research is librarybased that focuses on reading and analyzing both primary and secondary related materials. The primary materials are the actual sources of the law, which reflect the legislation and the case, including the application of stare decisis principle, where references shall be made to binding precedents. Next, secondary materials refer to commentary on the law studied, which are found in intervention textbooks and legal journals. More often, reference sources, such as legal encyclopedias, case digests, case citators, and online databases, for instance, Lexis Nexis, Wiley, Lawnet, Justcite, ISI, and Scorpus journals, are required to index and to gain access to the primary sources. As such, the content analysis method, which is based highly on literature review, as well as data primarily retrieved from case laws and legislation in Malaysia, had been employed to gather data from online databases and analysed with the aim of providing a review of the Malaysian law, particularly on exclusion clause, along with its legislative control.

\subsection{Results}

Regulations related to unfair terms in contracts can affect many business sectors, mainly trades that deal with consumer contracts that are of standard form type. These regulations ascertain a just trading environment and the protection of consumers. The Sale of Goods Act 1957 is one law in Malaysia that has an impact upon the exclusion clause, which embeds important principles stipulated within the case law. The Sale of Goods Act 1957 is meant to govern trade affairs of 'business and consumers' (B2C) and 'business and business' (B2B) but does not protect its consumers due to an integration of exclusion clauses. Section 62 of the Sale of Goods Act 1957 permits the exclusion of terms and conditions through 'express agreement.' The section is read as follows:

Where any right, duty or liability may arise under a contract of sale by implication of law, it may be harmful or varied by express agreement or by the course of dealing between the parties, or by usage, if the usage is to bind both parties to the contract.

According to Mohammad Ariff J., in the case of Sheila a/l Sangar v Proton Edar Sdn Bhd \& Anor, CPA 1999 created a tribunal to uphold justice for consumers. Part IIIA of CPA 1999 lists the factors, where a tribunal or a court would consider analyzing either procedural or substantive unfairness that is illustrative in nature, in which most items do not require much 
judicial consideration as to their meaning, such as 'without adequate justification'; 'oppressive'; 'unconscionable'; 'reasonable standards of fair dealing'; which require more explanation (Sinnadurai, 2011). The terms are ambiguous, vague, and open for interpretation (Farhah, 2017). In Malaysia, CPA 1999 appears to be the primary statute that upholds consumer protection. It is under the jurisdiction of the Ministry of Domestic Trade, Cooperatives, and Consumerism; who is responsible for the protection of consumers. The CPA has been influenced one way or other by proper progressions in Australia, New Zealand, Canada, and the United Kingdom (Naemah, 2012). The introduction of CPA 1999 possesses some extent to enhance consumer rights stipulated in contracts. CPA, however, upon its initiation in 1999, failed to address other critical areas of protection, in particular, consumer protection in contract dealings that involve exclusion clauses to exempt traders of their contractual liabilities. Although section 6 of the CPA 1999 Act seems to prohibit contracting out the provisions of the Act, it has failed in blanketing the broad spectrum of an exclusion clause in consumer contracts and has some drawbacks, thus disappointing both consumers and activist groups.

The CPA 1999 Act is very limited in its application. Section 2(4) states "this Act is supplemental in nature and without prejudice to any other law regulating contractual relations." The term 'without prejudice' reflects placing CPA in an 'inferior' status, as compared to other legislation. Next, the term 'supplementary' literally means additional and complementary (Naemah, 2011). In this sense, CPA 1999 does not replace the existing law; it only supplements it by providing the consumer with additional protection above the existing legislation. Upon conflict with other legislation, other laws that regulate contractual relations shall prevail. The CPA 1999 legislation, however, shall not deter the operation of any other provision in other legislation, which impose a stricter duty on the seller or supplier than the legislation proposed. Thus, the CPA 1999 shall prevail in the absence of consumer protection provisions stated in the existing laws.

\subsection{SWOT Analysis (Strengths, Weaknesses, Opportunities and Threats)}

This major flaw detected in the Malaysian consumer protection law has been rectified with the initiation of Part IIIA of the Consumer Protection (Amendment) Act 2010. Part IIIA is embedded into the CPA 1999 to deal with unfair terms in consumer contracts. According to Pretam Singh and Rahazlan Affandi (2011), instead of enacting a wholly new statute, the Parliament has amended the existing CPA 1999 after embedding a new section into the existing Act 599, namely Part IIIA entitled 'Unfair Contract Terms.' In dealing with terms that are unjust, the CPA 1999 has integrated a new principle to divide the aspect of unjustness into 'substantive' and 'procedural.' The new law refers to an essential legislation piece initiated by the Parliament in Malaysia in the light of consumer protection and contract law. This is not only beneficial for consumers, but it may also affect the transactions of B2C by businesses and corporations that offer consumer services and goods (Sinnadurai, 2011).

Furthermore, the amendment seems to adopt the proposal found in Indian Law Commission Report on Unfair (Procedural \& Substantive) Terms in Contract (2006), which divides unfairness into 'substantive' and 'procedural', for instance, in the USA, UK, Australia, Canada, and South Africa; which indicated that for the legislation to be more effective and 
realistic, it is important to separate the provisions to 'substantive' and 'procedural' unjustness (Sinnadurai, 2011). This idea of 'substantive' and 'procedural' unjustness, as initiated in Part IIIA of CPA, however, derives its authority from Hart v. O'Connor case, as well as in several kinds of literature (Naemah, 2011). The Indian Law Commission has conducted a study regarding unfair terms in contracts from different nations. Such a division has yet to be carried out in other nations to date. The Federation of Malaysian Consumers Associations (FOMCA) recommended that 'procedural' and 'substantive' unfairness must be distinguished for clarity to enhance consumer protection.

\subsection{Procedural unfairness}

Procedural unfairness refers to the very process of contract development. For instance, a purchaser is unaware of a term due to its small print at the time of signing a contract. Meanwhile, substantive unfairness focuses on the process outcome, for instance, the contract content. Exclusion of a party from negligence liability due to a clause refers to substantive unfairness. Furthermore, a term or a contract can be determined for its unfairness, either procedurally or substantively unfair. From the practical aspect, proving procedural unfairness seems to be more challenging, instead of proving substantive unfairness as the only relevant evidence is a copy of a contract that is unjust. However, these two conceptions overlap and differentiating them is not easy. This effect explains the reason unfair terms contract are not segregated in several nations. Section 24A(b) of CPA 1999 defines 'standard form contract' as "a consumer contract that is drawn up for general use in a particular industry, whether or not the contract differs from other contracts normally used in that industry." This provision incorporates contracts that are of standard form employed by many industries, such as insurance, banking, credit, and other supply of goods and services. Section 24(C) defines terms that are unfair as, "terms in a consumer contract which, about all the circumstances, causes a significant imbalance in the rights and obligations of the parties arising under the contract to the detriment of the consumer." Part IIIA emphasizes consumer protection and abhors unfair terms found in B2C contracts of standard form, including unfair terms commonly found in invoices, sale documents, and receipts (Naemah, 2011). The phrase 'significant imbalance' has yet to be defined by the Act. In general, as far as the common law is concerned, it is up to the court or tribunal to determine if a term causes significant imbalance by referring not only to the term itself but the whole contract as well.

Section 24C(1) of the CPA 1999 states that "a term or a contract is procedurally unfair if it has unjust advantage to the supplier or unjust disadvantage to the consumer on account of the conduct of the supplier or the manner in which or circumstances under which the contract or the term of the contract has been entered into or has been arrived at by the consumer and supplier". Meanwhile, section $24 \mathrm{C}(2)$ offers a rather lengthy list that depicts the factors the tribunal or the court shall take into consideration to identify procedural unfairness. The main reason is to ensure no element of one-sidedness in terms of procedure and contents (Naemah, 2011). In procedural unfairness, phrases such as 'knowledge and understanding', 'fine print', 'bargaining strength', 'linguistic disability', 'independent legal or other expert advice', and other circumstances spelt out in section $24 \mathrm{C}(2)$, are technical terms that may 
overlap with the provision of Contracts Act 1950 linked with mistake, misrepresentation, and undue influence (Sinnadurai, 2011).

\subsection{Substantive unfairness}

Section $24 \mathrm{D}$ (1) provides that a term or a contract is unfair substantively because "... if the contract or the term of a contract ...(d) excludes or restricts liability for negligence; or (e) excludes or restricts liability for breach of express or implied terms of the contract without adequate justification and if it involves harsh, oppressive and unconscionable." Part IIIA, thus, covers liability exclusion for both a contractual obligation and the tort of negligence. The CPA 1999, however, does not define the words 'unconscionable', 'difficult', and 'harsh' or the circumstances in which each will arise. For that, courts and tribunals should refer to prior judicial decisions as they are limited by stare decisis in interpreting what amounts to unconscionable, oppressive, and harsh terms. Consequently, it is argued that the bargaining power inequality doctrine refers to land law and should continue to be applied by courts and tribunals. Section $24 \mathrm{D}(2)$ reflects the circumstances for terms or contracts to be held void or unenforceable for substantive unfairness. Naemah (2011) asserted that section 24D(2), on general substantive unfairness, should be focused on the terms, instead of contract procedure.

\subsection{Discussion}

This article presents an evaluation of the effective legal control upon terms that are unjust, specifically the exclusion clause to vulnerable consumers. In Malaysia, the progression of contract law appears to display huge concern for consumer protection. The present contract law requires further improvisation in championing consumer rights. Unfortunately, the exclusion clause and agreement contents are not governed by the Contracts Act 1950.

In Malaysia, major legislative reforms and progressions have taken place to improvise protection of consumer since 1999. In reviewing the laws related to consumer protection enacted before 1999, several amendments and new laws have been introduced. The new laws generated in Malaysia for protection of consumers within this $21^{\text {st }}$ century are in line with the National Consumer Policy introduced in 2002 with the aim, inter alia, towards strengthening the institutionally legal framework for protection of consumers in Malaysia, as well as to stay abreast with new legal and policy amendments within the global market. As for Malaysia, its consumer contracts are mainly governed by the Consumer Protection Act (CPA) 1999, the Sale of Goods Act 1957, and the Contracts Act 1950. Sakina (2009) elaborated that both the Contracts Act 1950 and the Sale of Goods Act 1957 neither protect consumer rights nor reckon an unfair clause or term in a contract. However, CPA 1999, which is not in any way prejudice to other contractual regulations, seems to minimize the impact that paternalistic legislation has upon cases related to consumer rights.

Several cases in Malaysia have observed the increasing concern displayed by the courts regarding the embedded exclusion clauses in standard form type in many consumer contracts, where intervention by courts appears to vary based on different ideologies. The main rules used are those of 'incorporation' and 'construction.' In Malaysia, the principles of 
common law are employed to rule out liability exclusion based on sections 3 and 5 of the Civil Law Act 1956. Although the courts could not proscribe exclusion clauses due to the Theory of Contract, strict regulations have been developed for using these exemption clauses when interpreting them as contra proferentum, as well as for use in contracts.

Malaysian Airlines System Bhd v Malini Nathan \& Anor is a case illustrating a more lenient approach taken by the courts in deciding the incorporation of exclusion clause within the contract. In this case, breach of contract had been proven, and the Malaysian Airlines (MAS) was sued due to a failure of flying back to Kuala Lumpur the first respondent aged fourteen. Nonetheless, the Supreme Court held that MAS did not breach its contract and was right to rely on the clause found in Condition 9 that was printed on the airplane ticket. This portrays that the Malaysian courts are stringent in handling cases that involve negligence, particularly those related to exclusion clauses. As for Chin Hooi Chan v Comprehensive Auto Restoration Service Sdn Bhd \& Anor, the court took a stringent interpretation of these types of clauses due to negligence that led to damages. Nevertheless, in Premier Hotel Sdn Bhd v Tang Ling Seng, Elizabeth Chapmen's JC decision that was made in the Kuching High Court did cause several concerns due to the readiness displayed by the court in giving effect to evident and clear exclusion clause despite negligence.

Furthermore, the strict interpretation was noted upon exemption clause for Wee Lian Construction Sdn Bhd v Ingersoll-Jati Malaysia Sdn Bhd., which depicts a case that involved a machine purchased by the plaintiff that became defective after a few months. As the plaintiff invoked the Unfair Contract Terms Act (UCTA) 1977, the defendant relied on the exemption clause to deny liability. As a result, the court ruled out the inadequacy of applying UCTA 1977 within local legislation as the local law expressing permission to do so. The judge was of the view that the Specific Relief Act 1950 and the Contracts Act 1950 were appropriate for the case based on English common law. The judge claimed that local decisions are suitable enough and displayed full agreement with the contract law. It is for the legislature to make a move in promulgating such law if found necessary. The remarks passed by the judge have caused some concern. The unwillingness displayed by the court in acting for the best interest of the consumers is an area that lacks legal control, thus indeed a cause for concern.

Another case worth mentioning here is the case in 2001, whereby Saad Marwi v Chan Hwan Hua \& Anor emerged as a landmark case in Malaysia when inequality of bargaining power based on English doctrine was employed by the Court of Appeal, which extended that the courts in Malaysia should acknowledge this particular doctrine in the light of Section 3(1)(a) of the Civil Law Act 1956. For instance, Mr. Saad, a farmer who earned a living partially by harvesting coconuts on rented land from the respondent, a businessman. Saad also had a piece of land that was valued at about RM2.4 million (about US\$675,000). The respondent had managed to convince Saad to sell the land to him for just RM42,000 (about US $\$ 11,800)$. He even got Saad to sign a written agreement in English, in which Saad neither comprehended English nor was represented by a lawyer. Eventually, Saad decided to terminate the agreement.

Nonetheless, the judge of the Court of Appeal, Gopal Sri Ram JCA (as he then was) accepted the inequality of bargaining power doctrine in a rather extensive manner in his judgment through his statement given in the following: 
It is time to reckon a broader doctrine related to bargaining power inequality. Moreover, we have a reasonably wide choice on the route that we may take in our attempt to crystallize the law upon the subject. We can unconscionability applied the English doctrine in toto. That refers to a choice made available to us due to Section 3(1)(a) of the Civil Law Act 1956.

In Anthony Lawrence Bourke and Alison Deborah Essex Bourke v CIMB Bank Berhad Civil Appeal No W-02-(NCC)(W)-1345-07/2016, the appellants bought a piece of property on Jalan Sultan Ismail in Kuala Lumpur from a developer, Crest Worldwide Resources Sdn Bhd, in 2008. However, to finance the purchase, they took a loan from the defendant bank in the same year. It was a term loan agreement where the appellants would service the monthly, and the bank would essentially pay to the developer progress payments whenever they were due. However, CIMB failed to make payment on one of the invoices, and as a result, the developer terminated the entire sale and purchase agreement with the appellants. The appellants then lost their property due to the failure of CIMB to pay the sum due to the developer. In 2015, the Bourkes sued the bank for negligence and breach of contract. The counsel for appellants claimed that the exemption clause 12 stated in the agreement was breached under section 29 of the Contracts Act 1950 and was against public policy.

Hence, it did not refer to an absolute exemption on the bank's liability. The bank counsel, nonetheless, contended that the exemption clause, which is reflected one meaning only, must be enforced however unreasonable the court may think. Clause 12 of the Loan Agreement is exclusion clause that seems to exclude the liability of the bank's primary and general secondary obligations (CIMB Bank Bhd v Maybank Trustees Berhad and other appeals [2014] 3 MLJ 168 and Photo Production Ltd v Securicor Transport Ltd [1980] 1 All ER 556). However, the three-person bench chaired by Rohana Yusuf J with Vernon Ong Lam Kiat $\mathrm{J}$ and Hasnah Mohammed Hashim $\mathrm{J}$ in a unanimous decision held that the bank was liable for contract breach and tort due to its refusal in making the progress payment of housing loan to the developer. The exclusion clause of liability stated in the agreement was deemed as non-sustainable and cannot protect the bank from its liability :

"... [55] In the circumstances we are of the considered view that Clause 12 contravenes section 29 of the Contracts Act because, in its true effect, it is a clause that has effectively restrained any form of legal proceedings by the appellants against the bank. The current appeal can demonstrate that despite our findings on the breach by the bank, in this case, if Clause 12 is allowed to stay, it would be an exercise in futility for the appellants to file any suit against the respondent bank [57]. We find the bank was in breach of the fundamental term of the Loan Agreement in failing to pay the Invoice in accordance to its term, which had directly caused SPA termination; causing the appellants to suffer loss and damage... We further find Clause 12 in effect is a clause that restrains legal proceedings and [hence] it is void under section 29 of the Contracts Act...

\subsection{Conclusion}

In the realm of consumer contracts, consumers must not suffer due to the inherent weaknesses of the statutory provisions. Ad hoc approaches on a case-to-case basis are not appropriate for B2C e-commerce contracts (J., Sheela, 2014). The repercussion would defy the whole nation. Hence, a specific legislative shift in controlling the exclusion clauses 
embedded in consumer contracts is in dire need of change in Malaysia, not only due to the borderless nature of the blockchain technology, but also consumer contracts in e-commerce trend and lifestyle. The present provision on terms that are unfair in the CPA 1999 has raised several significant issues to be considered for implementation. The legislative enhancement in controlling terms that are unjustly embedded in consumer contracts in Malaysia displays the paternalistic initiative of the government in ensuring only a commercial environment that adheres to sustainable development goals (SDG). One important SDG is to reduce inequalities, where those vulnerable, such as consumers, are given protection from exploiting and manipulative terms (Sakina, 2011). In order to address these barriers, specific legislation must be enacted for e-commerce consumer contracts to adhere to technological specificity of e-commerce (J., Sheela, 2012). Thus, enacting specific laws as the legislative measure is required for controlling exclusion clauses incorporated in consumer contracts, as the law must also be abreast with the current needs of the society and to protect consumer rights in this 21 st-century era. The role of such legislation should be able to regulate exclusion clauses. Besides, the goal of the legislation is to reduce the gap of bargaining power inequality among traders with consumers, apart from seeking justice in e-commerce consumer contracts too, especially when protecting consumers is at the forefront.

\section{Acknowledgment}

The authors would like to express their gratitude to Institute of Research Management \& Innovation (IRMI) \& Institute of Quality and Knowledge Advancement (InQKA), Universiti Teknologi MARA, Shah Alam, Selangor for their financial assistance.

\section{References}

Abdullah, N.C., et.al. (2018).Attitudes of Sub-Sale Home Buyers and Vendors in the 21st Century: Legal implications. Asian Journal of Quality of Life (AjQoL), 3(13) Sep/ Oct 2018 (p.1-7).

Abdullah, N.C., et.al. (2018). Healthcare Internationalisation: An analysis of the behaviour of medical practitioners towards local patients. Environment- Behaviour Proceedings Journal. AicE-Bs2018Sheffield. 8th Asia-Pacific International Conference on Environment-Behaviour Studies The University of Sheffield, UK. 14-15 July 2018 (p.2531).

Anthony Lawrence Bourke and Alison Deborah Essex Bourke v CIMB Bank Berhad Civil Appeal No. W-02-(NCC) (W)-1345-07/2016.

Chin Hooi Chan v Comprehensive Auto Restoration Service Sdn Bhd \& Anor [1995] 2 MLJ 100. CIMB Bank Bhd v Maybank Trustees Berhad and other appeals [2014] 3 MLJ 168.

David, Y. (1986). Exclusion clauses in contracts. London: Sweet \& Maxwell.

Farhah Abdullah and Sakina Shaik Ahmad Yusoff (2017) Intervensi Perundangan Dalam Pengecualian Liabiliti bagi Kontrak Pengguna di Malaysia. 2017 Tuanku Jaafar International Conference, Universiti Kebangsaan Malaysia, 2023 November 2017. 
Jill.P.(2008). Textbook on Contract Law. Oxford: Oxford University Press.

Kho Feng Ming \& Sakina Shaik Ahmad Yusoff, (2017). Public Policy in Contracts: The Legal Inconsistencies In Malaysia, Proceeding - Kuala Lumpur International Communication, Education, Language and Social, Sciences 7 (KLiCELS 7), 22 - 23 July 2017. Hotel Bangi-Putrajaya, Bandar Baru Bangi, Malaysia, 350-357.

Llewellyn. K. (1939) 52 Harv L R 700,704.

Malaysian Airlines System Bhd v Malini Nathan \& Anor [1986] 1 MLJ 330.

Marzukhi, M.A., et.al. (2018). Re-appraising Regulatory Framework of Planning and Land Law System towards Sustainable Development in Malaysia. Asian Journal of Behavioural Studies (AjBeS), 3(9) Jan / Feb 2018 (p. 153 160).

Naemah Amin (2011.) The Nature of the Law on Consumer Protection, Law \& Commerce: The Malaysian Perspective, in Mohammad Naqib, Kuala Lumpur: IIUM Press.

Norliza Abdul Hamid \& Hariati Mansor (2011) The Legal Implications of the Consumer Protection (Amendment) Act 2010 on Contract Terms in Malaysia. Annual Summit on Business and Entrepreneurial Studies (ASBES 2011) Proceeding, 471, 481-482. 